\title{
The potential share of coal liquefaction in the Indonesian economy in 2025
}

\author{
Ukar Wijaya Soelistijo 1, ", Aryo Prawoto Wibowo², Makmun Abdullah ${ }^{3}$ \\ ${ }^{1}$ University of Islam Bandung, Institute of Technology Bandung, Mineral and Coal Technology R\&D Center, Bandung Indonesia \\ ${ }^{2}$ Institute of Technology Bandung, Bandung Indonesia \\ ${ }^{3}$ Institute of Technology Bandung, Center for Education and Training Center for Mineral and Coal, Bandung Indonesia
}

\section{Email address:}

ukar@tekmira.esdm.go.id (U.W. Soelistijo), ukarws@yahoo.com(U. W. Soelistijo), arwi@mining.itb.ac.id (A. P. Wibowo), makmunabd@gmail.com (M. Abdullah)

\section{To cite this article:}

Ukar Wijaya Soelistijo, Aryo Prawoto Wibowo, Makmun Abdullah. The Potential Share of Coal Liquefaction in the Indonesian Economy in 2025. Earth Science. Vol. 2, No. 6, 2013, pp. 149-157. doi: 10.11648/j.earth.20130206.16

\begin{abstract}
One of the objectives of the National Energy Policy (KEN) of Indonesiawhich is listed in Perpres (Presidential Regulation) number 5/2006 is the realization ofan optimal energy mix in 2025 by lowering oil consumption to $20 \%$ and increased utilization of coal to greater than $33 \%$. KEN also mandates that more than $2 \%$ of national energy needs is derived from coal liquefaction process. This research aim is to analyze atthe economic impact and linkages among sectors using Indonesian 2005 Input-Output Table which will be projected to 2025 by entering low-rank coal synthetic oil (CSO) sector as a new classification. Econometric models (regression analysis) and linear programming are applied in this research. The result of economic calculation of investation in CSO plants indicates that on the coal price assumption of US\$60/ton, synthetic coal oil price of US\$111/bbl, and the interest rate (i) 5\%, in general will give the Internal Rate of Return (IRR) is less than $10 \%$. Analysis of backward linkages shows that the CSO sector will have a potential increasing a new output for the economy higher than the other energy sectors, but lower rate of forward linkage (downstream). Meanwhile, the multiplier effect indicates that the development of CSO plant is capable of moving national economy sectors equivalent to the petroleum refining sector and other energy provider sectors. The lower surplus multiplier shows that the investment in the CSO sector will be attractive if the government gives incentives on the enterprise, things such as regulation and investing financial support, tax incentives/tax holiday, price subsidies, and the coal prices scheme arrangements.
\end{abstract}

Keywords: Energy Policy, Coal Liquefaction, Linkages, Multiplier, Linear Programming

\section{Introduction}

Oil plays an important role in the Indonesia's economy, either as fuel, raw materials of the production, or export commodity which until recently still is an important source of government revenue. Indonesia's dependence on oil in the long term threaten the sustainability of the national economic growth. In factin recent years Indonesia has become net importer of petroleum.

Meanwhile, Indonesia has coal resources of 105.2 billion tons, of which about 21.1 billion tonnes are reserves. Some of these resources, approximately $20.2 \%$ (21.25 billion tons) is low rank coal (Badan Geologi, 2012).

If each ton of low rank coal can be converted into two barrels of synthetic oil, it can produce about 42.5 billion barrels of synthetic oil (Daulay, 2008). This amount is 10.5 times the proven oil reserves of Indonesia which is currently at 4.04 billion barrels (per-January 2011).

$\mathrm{CSO}$ as an alternative fuel would save foreign exchange by considering that since 2003 Indonesia has become a net importer of petroleum and 2015 could be a net consumer if new reserves aren't found (Figure 1).

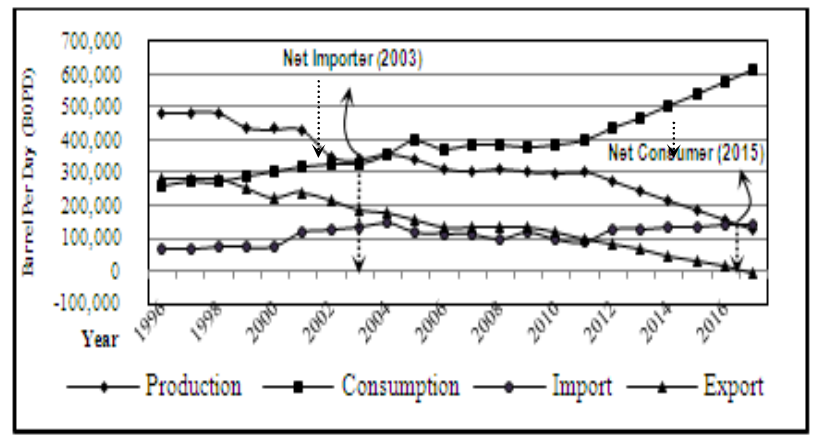

Source: DitjenMigas 2012 and reprocessed

Figure 1.Crude Oil Supply and Demand (Bbbl Oil Per Day/BOPD)

Indonesia in cooperation with Japan (NEDO) has conducted several feasibility studies of development of liquefaction plant through technology of improved-Brown 
Coal Liquefaction (I-BCL). The production of I-BCL is in the form of synthetic crude oil whose characteristics are similar to petroleum. Through the stages of fractionation and purification, the crude oil can be converted into premium (gasoline), kerosene, diesel oil/diesel, and other chemical products (Huda, 2008) (Table1).

The result of the feasibility study conducted in PT Arutmin, Mulia, South Kalimantan and PT Pendopo Energy Coal, South Sumatera shows that the economies level of liquefaction plant is influenced by the quality parameters of coal as raw material (Tables 2 and 3 ).

Economic calculation results are showing that on the assumption of coal price of US\$60/ton, oil price of US $\$ 111 / \mathrm{bbl}$ synthetic, and the interest rate (i) of 5\%, CSO plant investment in larger capacity, generally will provide the Internal Rate of Return (IRR), Profitability Index (PI), and Payback Period are better when compared with smaller capacity plant (Table 3 ).

Table1. The product spesification of coal liquefaction (I-BCL)

\begin{tabular}{lcccc}
\hline Fuel Type & Unit & I-BCL Products & Indonesia & Industry Standard \\
\hline Gasoline: & & & Min. 88 & Min. 89 \\
-Octane Number & & Min. 90 & Max. 0.2 & - \\
-Sulfur Content & Wt $\%$ & Max. 0.005 & Min. 16 & Min. 23 \\
$\begin{array}{l}\text { Kerosene: } \\
\text {-Smoke point }\end{array}$ & Mm & Min. 16 & Max. 0.015 \\
-Sulfur Content & Wt $\%$ & Max. 0.005 & Max. 0.2 & Min. 45 \\
$\begin{array}{l}\text { Gas Oil: } \\
\text {-Cetane Number }\end{array}$ & & Min. 45 & Min. 45 & Max. 0.2 \\
-Sulfur Content & Wt $\%$ & Max. 0.005 & Max. 0.5 & \\
\hline
\end{tabular}

Source: Direktorat Jenderal Minyak dan Gas, 2012; Direktorat Jenderal Mineral dan Batubara, 2012; Huda, 2008; Daulay, 2008.

Table 2. Feed coal characteristics of coal synthetic oil pilot plant

\begin{tabular}{lcc}
\hline Quality Parameter & Mulia & Pendopo \\
* Total Moisture (ar) & $35.00 \%$ & $55.00 \%$ \\
* Proximate analysis (adb) & & \\
- Inherent Moisture & $23.00 \%$ & $15.90 \%$ \\
- Ash & $3.90 \%$ & $7.80 \%$ \\
- Volatile matters & $38.10 \%$ & $44.80 \%$ \\
- Fixed carbon & $35.10 \%$ & $31.60 \%$ \\
- Total sulphur & $0.15 \%$ & $2.50 \%$ \\
\hline
\end{tabular}

Source: Huda, 2008

Table 3. Analysis result of financial aspect of coal synthetic oil plant

\begin{tabular}{|c|c|c|c|c|}
\hline Plant Capacity & $\begin{array}{c}\text { IRR } \\
(\%)\end{array}$ & $\begin{array}{l}\text { NPV } \\
\text { (US\$) }\end{array}$ & PI & $\begin{array}{c}\text { Payback Period } \\
\text { (Years) }\end{array}$ \\
\hline \multicolumn{5}{|l|}{ Mulia Coal: } \\
\hline$* 3000(\mathrm{t} / \mathrm{d})$ & 5.78 & $158,186,264.13$ & 1.11 & 17.98 \\
\hline$* 6000(\mathrm{t} / \mathrm{d})$ & 7.06 & $876,090,838.51$ & 1.37 & 13.02 \\
\hline$* 12000(\mathrm{t} / \mathrm{d})$ & 9.17 & $2,746,042,296.88$ & 1.66 & 9.98 \\
\hline \multicolumn{5}{|l|}{ Pendopo Coal: } \\
\hline$* 3000(\mathrm{t} / \mathrm{d})$ & 0.43 & $-769,597,990.71$ & 0.49 & 56.71 \\
\hline$* 6000(\mathrm{t} / \mathrm{d})$ & 3.23 & $-567,477,287.41$ & 0.77 & 29.29 \\
\hline$* 12000(\mathrm{t} / \mathrm{d})$ & 4.70 & $-176,190,295.91$ & 0.96 & 21.95 \\
\hline
\end{tabular}

Source: Huda, 2008 and re-calculated.

\section{Theory and Methodology}

\subsection{Theory}

In the long effort of the development of coal diversification in Indonesia that has been carried out to face the reality that the domestic oil reserve depletion happened within the last 40 years due to the sharp increasing domestic consumption. Since there are available domestic large quantity of coal resources, then all efforts of coal diversification are carried out to overcome the energy problem, towards utilizing the new and renewable energy sources in the future. Diversification of coal utilization may include several processes as the followings:

a. Direct utilization.

In the world wide coal has be used as direct fuel in industry for instance steam generating power plant, cement industry, steel plant, drying oven, small industry.

b. Indirect utilization.

Indirect coal utilization could be carried out in several processes:

i. Coking process.

Coking process or carbonization is principally conducted by reducing the content of volatile content in coal, so that 
its content of fixed carbon increases in lieu with the increasing its porosity. The product of coke has usually high compressive strength, content of fixed carbon and calorific value. The coking process could be carried out through either direct process or double process, depending on the purpose of coke making and the quality of coal. Domestic consumption of cokes which is mostly for iron casting, is around 140,000 tons per year but still be imported. It is expected that the domestic production of foundry cokes could be met soon (Anonymous (d), 1980; Soelistijo, 2011).

ii. Coal gasification. (Anonymous (b), 2008; Anonymous (a), 2007; Anonymous (c), 2000; Anonymous (d), 1980).

Principally, coal gasification process converts solid coal mass into syntheticgas that could utilized as fuel or raw material in chemical industry. Several example processes are: Lurgi fixed bed, Winkler fixed bed, Kopper-Totzek entrained bed, Tigar twin fluidized bed. MCTRDC has developed direct coal gasification process resulting producer gas for tea leaf drying in the tea plantation and also for mixed oil-gas fuels in diesel generating power plant. In principle, the chemical reaction of resulting syngas and producer gas is as the followings:

$$
\text { gasification }
$$

$\mathrm{Coal}+\operatorname{air}\left(\mathrm{O}_{2}+\mathrm{N}_{2}\right)+$ steam $\rightarrow \mathrm{CO}+\mathrm{H}_{2}+\mathrm{N}_{2} \quad \ldots$ (producer gas, for heating)

$\mathrm{Coal}+\mathrm{O}_{2}+$ steam $\rightarrow \mathrm{CO}+\mathrm{H}_{2} \ldots \ldots$...(syngas, for fuel, chemical feedstock, synthetic oil and synthetic natural gas)

iii. Coal liquefaction. (Anonymous (d), 1980; Anonymous (e), 2002; Anonymous (f), 2003; Wasaka, 2006).

Coal liquefaction process has four flows of processes (Figure 2) as follows:

- Pyrolisis or carbonization.

- The example processes: COED, TOSCOAL, GARRET and Clean-coke have been developed.

- Solvent extraction.

- The example processes: CSF (Consol Synthetic Fuel Process (CSF 2-3 : 1 solvent/coal ratio), SRC (Pittsburgh \& Midway solvent refining process).

- Hydrogenation by using catalyst.

- The example processes: H-Coal process, Synthetic oil process, CCL (Catalytic Coal Liquefaction) process.

- Indirect liquefaction.

- The new direct liquefaction by using catalyst is being developed by JICA Japan.

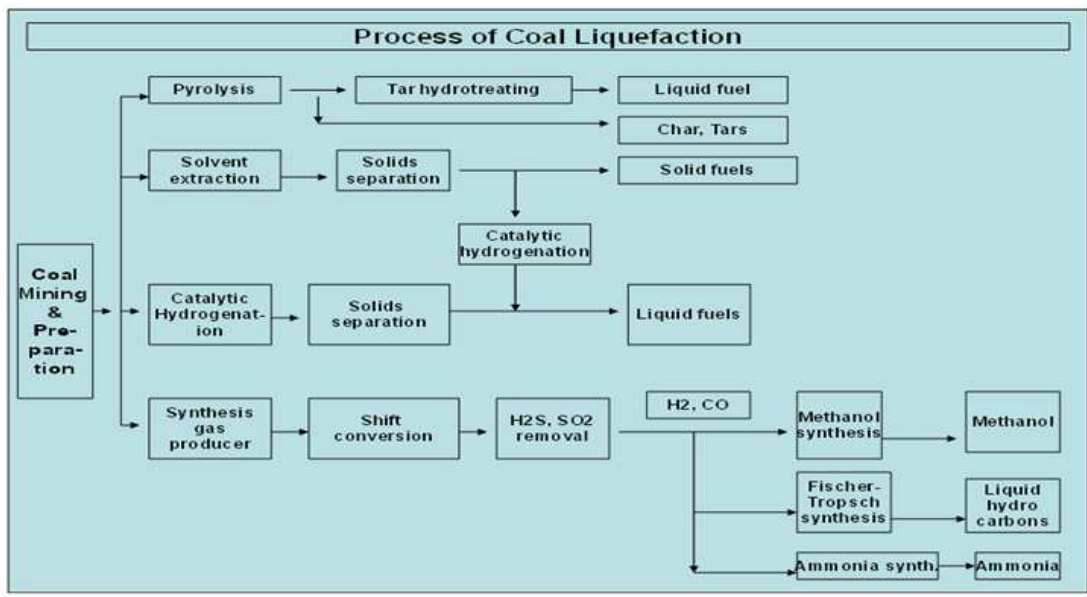

Figure 2. Several flows of coal liquefaction process

Besides coal could be utilized as fuels, it can also be used as non-fuel usage such as activated carbon, and other chemical substances.

\subsection{Methodology}

This study aimsto quantify the economic impact ofthe utilization of low quality coal through coal liquefaction process using an Input-Output model based on Indonesian 2005 Input-Output Table, 175x175sectors, domestic transactions on the basis of producer prices (Badan Pusat Statistik, 2005).

This table will be projected to year 2025 by entering alow-rank CSO sector asa new classification. The projection will be carried out in two assumptions that are the Scenario $1\left(\mathrm{~S}_{1}\right.$, low) with an economic growth of $6 \%$ and Scenario $2\left(\mathrm{~S}_{2}\right.$, high) with 7\% in $2010-2015$ and $8 \%$ in 2015-2025 (Menko Perekonomian, 2011). Final demand will be projected based on regression analysis, while optimization using linear programming.
The output valueof CSO sectors that is allocated to meet the demand for intermediate and final demand is 80.5 million barrels (BP-PEN, 2010). While the value of goods and services used as inputs in the production of CSO will be based on the results of a feasibility study of coal liquefaction plant (Huda, 2008; Anonymous (g), 2011; Anonymous (h), 2011; Soelistijo, 2003, 2013).

How high the linkage strength of the CSO sector with the the other sectors is measured by the backward $(\alpha \mathrm{j})$ and forward $(\beta i)$ linkages. The backward linkage measures the yield of the CSO sector compared with input sectors, and forward linkage measures the strength of linkge of the CSO sector with the other sectors in creating higher added value. Multiplying analysis is used to clarify changes in the endogenous variables that are sectoral output as response to changes in exogenous variables in this case of final demand. The analysis results are used to set targets and allocation of development. Multiplying effects may include such as surplus-, investment-, added value-, and employment 
multipliers. In particular, surplus multiplier indicates how far the development of CSO plant development in Indonesia provide enough surplus for the investors. Moreover, to evaluate the potential desired objective optimally in the scope of inputs and or outputs sectors, linear programming Input-Output model is applied subject to the available constraints due to the limited resources available. All in all, the entire study would like to see in depth how far the plan of CSO plant development in 2025 based on the certain scenarios is expected to contribute to the national economy output.

\section{Analysis and Discussion}

\subsection{Input-Output Model Definition}

I-O Table is a comprehensive data set, consistent, and detailed statistical description of shape in the matrix.

Thatshows the structure of an economy's entire production system for a particular period of time, usually for a calendar or financial year. It shows goods and services produced by each industry, how such goods and services are used by different users; whether as intermediate inputs in production or final consumption.

\subsubsection{Relationship of the Entries in the I-O Table}

The relationship betweenthe entries inI-O Table andGDPare asfollows:

$$
\sum_{j} X_{i j}+Y_{i}-M_{i}=X_{i}(i=1,2, \ldots, n)
$$

Where:

$\mathrm{X}_{\mathrm{ij}}=$ transactionsfrom $\mathrm{i}$ sectorto jsector,

$\mathrm{Y}_{\mathrm{i}}=$ final demand of $\mathrm{i}$ sector,

$\mathrm{M}_{\mathrm{i}}=$ importsof $\mathrm{i}$ sector,

$\mathrm{X}_{\mathrm{i}}=$ total output i sector.

$$
\sum_{i} X_{i j}+V_{j}=X_{i}(\mathrm{j}=1,2, \ldots, \mathrm{n})
$$

In this case $_{j}$ is the primary inputs (value added) of $\mathrm{j}$ sector. Because $X_{i}=X_{j}$, the formula can be written as follows:

$$
\sum_{j} X_{i j}+Y_{i}-M_{i}=\sum_{i} X_{i j}+V_{j} \text { or }_{\mathrm{Y}_{\mathrm{i}}}-\mathrm{M}_{\mathrm{i}}=\mathrm{V}_{\mathrm{j}}
$$

From the I-O table,the technical coefficients $\left(a_{i j}\right)$ measure the input requirements per unit of product.These coefficients stated as the ratio between the outputs of $i$ sector used in $j$ sector $\left(X_{i j}\right)$ with total input $j$ sector $\left(x_{j}\right)$ is determined as follows:

$$
a_{i j}=\frac{X_{i j}}{X_{j}} \text { or } X_{i j}=a_{i j} \cdot X_{j}
$$

Furthermore, output in the I-O models calculated by the equation:

$$
\begin{gathered}
(I-A) X=Y \\
X=(I-A)^{-1} Y
\end{gathered}
$$

In the equation written above, $(I-A)^{-1}$ is the inversed matrix from $(I-A)$ or it can be called as Leontiefinversed matrix (Bulmer, 1982; Nazara, 2005; Soelistijo, 2013).
Outputin the economyof a countryin the I-O modeldeveloped byBulmercan be calculatedas follows:

$$
X=(I-A)^{-1} Y
$$

where:

$\mathrm{Y}=$ final demand,

$\mathrm{I}=$ identity matrix,

A $=$ technical coefficient.

Leontief inversed matrix $(I-A)^{-1}$ is very important to analyze the economy because of inter-related with the level of final demand to the estimation of production rate. Changes in industry output can be predicted using the Leontief inversed matrix.

\subsubsection{Intersectoral Linkages Analysis}

This analysisis used to look at thei mpact happened on output of a sector as a result of changes infinal demandin each sector of the economy. Impact of industrial linkages between sectors can be observed through backward linkages and forward. Backward linkages of a sector with other economic sectors in a region/country (Bulmer, 1982, Miernyk, 1965,1982) are calculated with the formula:

$$
\propto_{j}=\frac{\left(1 /{ }_{n}\right) \sum_{i} b_{i j}}{\left(1 /{ }_{n^{2}}\right) \sum_{i} \sum_{j} b_{i j}}
$$

While a sector forward linkage with other sectors is used an equation:

$$
\beta_{i}=\frac{\left(1 /{ }_{\mathrm{n}}\right) \sum_{\mathrm{j}} \mathrm{b}_{\mathrm{ij}}}{\left(1 /{ }_{\mathrm{n}^{2}}\right) \sum_{\mathrm{i}} \sum_{\mathrm{j}} \mathrm{b}_{\mathrm{ij}}}
$$

\subsubsection{Multiplier Analysis}

Multiplier analysis is used to see changes in the endogenous variablesthat aresectoral output as response to changes in exogenous variables such as final demand (Nazara, 2005). The results ofthe analysisare used toset targets and allocation of development.

\subsection{Linear Programming Approaches}

Linear programming $\mathrm{I}-\mathrm{O}$ models is a mathematical model for utilizing the limited resources in meeting the desired objectives optimally in the scope of input and output sectors.

Value projection in the I-O table is not necessarily the optimal value, because it will be optimized using linear optimization program with the objective function to maximize the final demand $(Y i)$ and total output $(X i=X j)$ in I-O Table 2025 (coefficient of objective can be seen in Tables 4 and 5).

Table 4. Objective function coefficient of I-O Table in Scenario 1

\begin{tabular}{clcc}
\hline No. & Sector/Industry & $\begin{array}{c}\text { Final } \\
\text { Demand }(\boldsymbol{Y})\end{array}$ & $\begin{array}{c}\text { Total } \\
\text { Output }(\boldsymbol{X})\end{array}$ \\
\hline 1 & Coal mining & 0.815679 & 1.282149 \\
2 & Coal synthetic oil & 0.644245 & 1.520398 \\
3 & Natural gas and geothermal & 0.861802 & 1.221582 \\
4 & mining & 0.923090 & 1.128445 \\
5 & Oetroleum refineries products & 0.588596 & 1.671504 \\
\hline
\end{tabular}

Source: 2025 IO Tabe in Scenario 1 
Table 5.Objective function coefficient of I-O Table in Scenario 2

\begin{tabular}{clcc}
\hline No. & Sector & $\begin{array}{c}\text { Final } \\
\text { Demand }(\boldsymbol{Y})\end{array}$ & $\begin{array}{c}\text { Total } \\
\text { Output }(\boldsymbol{X})\end{array}$ \\
\hline 1 & Coal mining & 0.815679 & 1.282249 \\
2 & Coal synthetic oil & 0.631941 & 1.556405 \\
3 & Natural gas and geothermal & 0.861802 & 1.221644 \\
4 & mining & 0.923116 & 1.128440 \\
5 & Petroleum refineries product & 0.588471 & 1.672003 \\
\hline
\end{tabular}

Source: 2025 I-O Table in Scenario 2
In this linear program will be used five decision variables, that iscoal mining sector, $\mathrm{CSO}$, natural gasand geothermal mining, petroleum refineries product, and other sectors which is a combination of 21 other economic sectors.

While limit function for each economic sector are import and primary inputs (added value) that indicating the amount of the remuneration of the factors of production, which consists of wage and salary, operating surplus, depreciation, indirect tax, and subsidy (See Tables 6 and 7).

Table 6.Minimum limit coefficient of primary input (Scenario 1)

\begin{tabular}{|c|c|c|c|c|c|c|}
\hline No. & Sector (Constraint) & Coal mining & $\begin{array}{c}\text { Coal Synthetic } \\
\text { Oil }\end{array}$ & $\begin{array}{l}\text { Natural Gas and } \\
\text { Geothermal Mining }\end{array}$ & $\begin{array}{c}\text { Petroleum refineries } \\
\text { product }\end{array}$ & Others \\
\hline 1 & Capital & 0.04763 & 0.12057 & 0.02302 & 0.08838 & 0.04989 \\
\hline 2 & Labor & 0.16092 & 0.00664 & 0.05645 & 0.22337 & 0.15545 \\
\hline 3 & Operating Surplus & 0.54171 & 0.29297 & 0.73684 & 0.64457 & 0.27001 \\
\hline 4 & Indirect Tax & 0.03359 & 0.17407 & 0.04176 & 0.00641 & 0.01948 \\
\hline 5 & Subsidy & 0.00000 & 0.00000 & 0.00000 & -0.36055 & -0.00223 \\
\hline 6 & Imports & 0.03184 & 0.05000 & 0.00373 & 0.32091 & 0.09601 \\
\hline
\end{tabular}

Source: direct coefficient of 2025 I-O table in Scenario 1

Table 7.Minimum limit coefficient of primary input (Scenario 2)

\begin{tabular}{|c|c|c|c|c|c|c|}
\hline No. & Sector (Constraint) & Coal mining & $\begin{array}{c}\text { Coal Synthetic } \\
\text { Oil }\end{array}$ & $\begin{array}{l}\text { Natural Gas and } \\
\text { Geothermal Mining }\end{array}$ & $\begin{array}{c}\text { Petroleum refineries } \\
\text { product }\end{array}$ & Others \\
\hline 1 & Capital & 0.04763 & 0.09536 & 0.02302 & 0.08838 & 0.04989 \\
\hline 2 & Labor & 0.16092 & 0.00525 & 0.05645 & 0.22338 & 0.15556 \\
\hline 3 & Operating surplus & 0.54171 & 0.23171 & 0.73684 & 0.64459 & 0.26972 \\
\hline 4 & Indirect tax & 0.03359 & 0.24962 & 0.04176 & 0.00641 & 0.01944 \\
\hline 5 & Subsidy & 0.00000 & 0.00000 & 0.00000 & -0.36056 & -0.00223 \\
\hline 6 & Imports & 0.03184 & 0.05000 & 0.00373 & 0.32091 & 0.09609 \\
\hline
\end{tabular}

Source: direct coefficient of 2025 I-O table in Scenario 2

Table 8. The projection result offinal demand (Y) andtotaloutput (X) (IDR Trillion)

\begin{tabular}{|c|c|c|c|c|c|c|}
\hline \multirow[t]{2}{*}{ No. } & \multirow[t]{2}{*}{ Sector } & \multirow[t]{2}{*}{2005} & \multicolumn{2}{|c|}{$\begin{array}{c}\text { I-O Table in } \mathbf{2 0 2 5} \\
(\text { Scenario } 1)\end{array}$} & \multicolumn{2}{|c|}{$\begin{array}{c}\text { I-O Table in } 2025 \\
\text { (Scenario 2) }\end{array}$} \\
\hline & & & Actual & Optimal & Actual & Optimal \\
\hline 1 & Final Demand & $3,443.895$ & $11,896.839$ & $11,167.340$ & $15,019.635$ & $15,019.570$ \\
\hline 2 & Total Output & $5,688.274$ & $19,813.284$ & $32,727.790$ & $25,022.737$ & $41,350.150$ \\
\hline
\end{tabular}

Source: optimization result of I-O table using linear programming

The linear programming model is formulated as follows: Maximize:

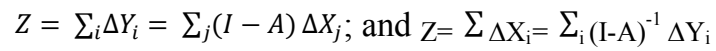

Subject to constraints:

Capital: $\sum k_{j} X_{j}-D_{h} \leq K_{h}$;

Labor: $\sum \mathrm{l}_{\mathrm{j}} \mathrm{X}_{\mathrm{j}}-\mathrm{E}_{\mathrm{h}} \leq \mathrm{L}_{\mathrm{h}}$;

Operating surplus: $\sum_{\mathrm{j} \mathrm{X}_{\mathrm{j}^{-}}} R_{\mathrm{h}} \leq S_{\mathrm{h}^{\prime}}$;

Indirect tax: $\sum_{\mathrm{j}} \mathrm{X}_{\mathrm{j}^{-}} P_{\mathrm{h}} \leq T_{\mathrm{h}^{\prime}}$

Subsidy: $\sum b_{\mathrm{j}} \mathrm{X}_{\mathrm{j}-} F_{\mathrm{h}} \leq B_{\mathrm{h}}$;
Imports: $\sum \mathrm{m}_{\mathrm{j}} \mathrm{X}_{\mathrm{j}} I_{\mathrm{h}} \leq M_{\mathrm{h}}$

Non-negativity: $X_{1} \geq 0, X_{2} \geq 0, \ldots X_{n} \geq 0$; where:

$\mathrm{Z}=$ obejctive function; $\quad \mathrm{X}=$ total gross ouput;

$\mathrm{Y}=$ final demand;

$\mathrm{A}=$ techncal ciefficient;

$\mathrm{k}_{\mathrm{i}}=$ capital coefficients;

$\mathrm{J}_{\mathrm{i}}=$ subsidy coefficients;

$\mathrm{K}_{\mathrm{h}}=$ available capital;

$\mathrm{B}_{\mathrm{h}}=$ available subsidy;

$\mathrm{l}_{\mathrm{i}}=$ labor coefficients;

$\mathrm{t}_{\mathrm{i}}=$ indirect tax coefficients;

$\mathrm{L}_{\mathrm{h}}=$ available labor;

$\mathrm{T}_{\mathrm{h}}=$ available indirect tax;

$\mathrm{s}_{\mathrm{i}}=$ operating surplus coef.; $\quad \mathrm{m}_{\mathrm{h}}=$ import coefficients;

$\mathrm{S}_{\mathrm{h}}=$ available surplus;
$\mathrm{M}_{\mathrm{h}}=$ available imports; 
$D_{h}, E_{h}, R_{h}, F_{h}, P_{h}, I_{h}=$ disposal activities.

\subsection{Coal Synthetic Oil Sector Impact on the Economy}

\subsubsection{The Economies of Coal liquefaction Plant}

Coal of Pendopo that has a higher moisture if compared with Mulia will cause a greater feed that will followed by the increase in the volume of equipment on the upstream plant, such as coal handling, water removal, and boiler design. Location of coal liquefaction plant on Pendopo also requires the availability of pipelines along the $200 \mathrm{~km}$ to the port in order to transmit CSO products.

Thus the costof procurement and construction of Pendopo plant which is calculated based onthe results ofa feasibility study in 2002 if assuming the price increase around 3.5\%/yearwill be US\$98 million higher compared with the Mulia plant.The operational cost of Pendopo coal liquefaction plant on the same coal price assumptions (US\$60/ton) will be higher (US\$88.65/bbl) than Mulia plants (US\$ 67.62/bbl).

The economic calculation result ofCSO plant shows that the value of IRRis less than $10 \%$ making it less attractive toinvestors. The value of IRR will be influenced by the price ofcoal, product selling prices, interest rates, and the amount of tax imposed on the company.

CSO plants would be built as an integrated industry between mining and coal liquefaction thus more productive and efficient. The regulation of low rank coal prices could bemade by government to ensure stability of supply and price. The investment of CSO plant would be more attractive to investors if the government can provide incentives, things such as:

- Reduction of coal production sharing (DHPB) and royalties;

- Reduction in corporate tax rate $(\mathrm{PPh})$;

- Exemption of import duty for imported capital goods;

- Elimination ofvalue added tax (PPN);

- $\quad$ Price subsidies.

\subsubsection{Linkages Analysis}

The impact of linkage is an important analytical tool in order to describe the role ofthe production sector in the structure ofthe economy and set the key sectors in the development planning.

The result analysis of backward linkages $\left(\alpha_{j}\right)$ is known that in general, energy providers sectors give lower yields than average of economic sectors.However, the CSO sector is known to have backward linkages value higher $\left(\mathrm{S}_{1}: \alpha_{3}=0.942\right.$ and $\left.\mathrm{S}_{2}: \alpha_{3}=0.958\right)$ when compared with petroleum refineries product sector $\left(\mathrm{S}_{1}: \alpha_{12}=0.679\right.$ and $\left.\mathrm{S}_{2}: \alpha_{12}=0.674\right)$ and other energy provider sectors. Meanwhile, forward linkages $\left(\beta_{i}\right)$ indicate that CSO sector has lower value $\left(\mathrm{S}_{1}: \beta_{3}=0.731\right.$ and $\left.\mathrm{S}_{2}: \beta_{3}=0.734\right)$ compared to the petroleum refineries product sector $\left(\mathrm{S}_{1}: \beta_{12}=1.333\right.$ and $\mathrm{S}_{2}: \beta_{12}=1.336$ ) and other energy providers.

\subsubsection{Multiplier Analysis}

The analysis of multiplieris carried out in an open method (Type I), which does not include household consumption as one of the sectors of production that is considered as an exogenous factor that does not determine the economy's output.

\subsubsection{Output Multiplier}

Output multiplier of CSO sector based on I-O table in 2025 on scenario 1 and 2 are 1.505 and 1.528. This mean sthat any increase in final demand $(\Delta \mathrm{Y})$ in this sector amounted to IDR1 billion, it will create theoutput $(\Delta X)$ amounting to IDR1.505 billion and IDR1.528 billion.

Output multiplier of CSO is higher when compared to coal mining sector $\left(\mathrm{S}_{1}: \mathrm{OM}=1.279\right.$ and $\mathrm{S}_{2}$ : $\mathrm{OM}=1.275)$,natural gas and geothermal mining $\left(\mathrm{S}_{1:}\right.$ $\mathrm{OM}=1.159$ and $\mathrm{S}_{2}: \mathrm{OM}=1.157$ ), and petroleum refineries product $\left(\mathrm{S}_{1}: \mathrm{OM}=1.085\right.$ and $\left.\mathrm{S}_{2}: \mathrm{OM}=1.075\right)$.

This indicates the ability of this new sector in creating a new output for the economy higher than the other energy provider sectors.

\subsubsection{Income Multiplier}

Income multiplier of CSO sector in scenario1 and 2are 3.85 and 4.60 , which means that any increase infinal demand $(\Delta Y)$ of IDR1 billion will increase the total revenue $(\Delta N)$ of the entire economy of 3.85 and 4.60 times than before.

The income multiplier of this sector is higher than the natural gas and geothermal mining sector $\left(\mathrm{S}_{1}: \mathrm{NM}=1.94\right.$ and $\left.\mathrm{S}_{2}: \mathrm{NM}=1.94\right)$, petroleum refineries products $\left(\mathrm{S}_{1}: \mathrm{NM}=1.58\right.$ and $\left.\mathrm{S}_{2}: \mathrm{NM}=1.66\right)$, and coal mining $\left(\mathrm{S}_{1}: \mathrm{NM}=1.37\right.$ and $\mathrm{S}_{2}: \mathrm{NM}=1.36$ ).

This shows the potential of this sector in creating household income due to the absorption of labor in meeting its production.

\subsubsection{SurplusMultiplier}

Surplus multiplier of CSOsectorbased on I-O table in 2025 on scenario 1 and 2 are 1.019 and 1.216. This mean sthat any investment inthis sector amounted to IDR1billion would generate a surplus from operations of IDR1.019 billion and IDR1.216 billion.

The value of surplus multiplieris lowerwhen compared to thenatural gas and geothermal mining $\left(\mathrm{S}_{1}: \mathrm{SM}=3.953\right.$ and $\left.\mathrm{S}_{2}: \mathrm{SM}=3.961\right)$, coal mining $\left(\mathrm{S}_{1}: \mathrm{SM}=1.803\right.$ and $\left.\mathrm{S}_{2}: \mathrm{SM}=1.807\right)$, and petroleum refineries products $\left(\mathrm{S}_{1}: \mathrm{SM}=1.222\right.$ and $\left.\mathrm{S}_{2}: \mathrm{SM}=1.376\right)$.

This indicates that the development of CSO plant in Indonesia provides enough surplus value for its investors.

\subsubsection{Investment Multiplier}

Investment multiplier of CSOsector in scenario1 and 2 of 1.242 and 1.333, which means that any increase in investment $(\Delta I)$ IDR1 billion, causing an increase innational income $(\Delta Y)$ amounting to IDR1.242 billion and IDR1.333 billion.

This investment multiplier is higher than coal mining sector $\left(\mathrm{S}_{1}: \mathrm{IM}=1.392\right.$ and $\left.\mathrm{S}_{2}: \mathrm{IM}=1.385\right)$, natural gas and geothermal mining sector $\left(\mathrm{S}_{1}: \mathrm{IM}=1.263\right.$ and $\left.\mathrm{S}_{2}: \mathrm{IM}=1.260\right)$, and petroleum refineries product sector $\left(\mathrm{S}_{1}: \mathrm{IM}=1.036\right.$ and $\mathrm{S}_{2}: \mathrm{IM}=1.036$ ).

It means that investment in the CSO sector will have a direct impact on national income equivalent to the others 
energy provider sector.

\subsubsection{Value Added Multiplier}

Value added multiplier of CSO on scenario 1 and 2 are 1.527 and 1.545 , which means that any increase in final demand $(\Delta Y)$ of a sector IDR1 billion will be able to move the economy and generate added value in other economic sectors amounted to IDR1.527 billion and IDR1.545 billion.

The value added multiplier of CSO sector is higherthan the petroleum refineries product $\left(\mathrm{S}_{1}: \mathrm{VM}=1.119\right.$ and $\left.\mathrm{S}_{2}: \mathrm{VM}=1.118\right)$, natural gas and geothermal mining $\left(\mathrm{S}_{1}: \mathrm{VM}=1.149\right.$ and $\left.\mathrm{S}_{2}: \mathrm{VM}=1.149\right)$, and coal mining $\left(\mathrm{S}_{1}: \mathrm{VM}=1.195\right.$ and $\left.\mathrm{S}_{2}: \mathrm{VM}=1.192\right)$.

\subsubsection{Employment Multiplier}

Employment multiplier of synthetic coal oil sector in scenariol and 2 are 1.424 and 1.925 , which means that any increase in final demand $(\Delta Y)$ in this sector of a unit of money, would drive the economy and absorb labor in other sectors amounted to 1.424 and 1.925 units.

The employment multiplier shows a higher value than coal mining sector $\left(\mathrm{S}_{1}: \mathrm{LM}=1.294\right.$ and $\left.\mathrm{S}_{2}: \mathrm{LM}=1.290\right)$, natural gas and geothermal mining sector $\left(\mathrm{S}_{1}: \mathrm{LM}=1.279\right.$ and $\left.\mathrm{S}_{2}: \mathrm{LM}=1.275\right)$ and petroleum refineries products $\left(\mathrm{S}_{1}: \mathrm{LM}=1.036\right.$ and $\left.\mathrm{S}_{2}: \mathrm{LM}=1.036\right)$.

\subsubsection{The Role of Coal Sybthetic Oil in the Economy}

The plan for CSO plant development in 2025 on the scenario is expected to contribute to national economic output of IDR65.033 trillion and in scenario 2 of IDR82.226 trillion, or $0.33 \%$ of the total output (X).

Objective Function:

$$
\mathrm{Y}=0.816 \mathrm{X}_{1}+0.644 \mathrm{X}_{2}+0.862 \mathrm{X}_{3}+0.923 \mathrm{X}_{4}+0.589 \mathrm{X}_{5}
$$

Subject to the constrants:

- Capital:

$$
0.05 \mathrm{X}_{1}+0.12 \mathrm{X}_{2}+0.02 \mathrm{X}_{3}+0.09 \mathrm{X}_{4}+0.05 \mathrm{X}_{5} \leq 1,005,800,909.34
$$

- Labor:

$$
0.16 \mathrm{X}_{1}+0.01 \mathrm{X}_{2}+0.06 \mathrm{X}_{3}+0.22 \mathrm{X}_{4}+0.15 \mathrm{X}_{5} \leq 3,086,439,072.51
$$

- $\quad$ Operating surplus:

$$
0.54 X_{1}+0.29 X_{2}+0.74 X_{3}+0.64 X_{4}+0.27 X_{5} \leq 5,637,843,521.49
$$

- Indirect tax:

$$
0.03 \mathrm{X}_{1}+0.17 \mathrm{X}_{2}+0.04 \mathrm{X}_{3}+0.01 \mathrm{X}_{4}+0.02 \mathrm{X}_{5} \leq 395,956,904.61
$$

- Subsidy:

$$
0.00 \mathrm{X} 1+0.00 \mathrm{X}_{2}+0.00 \mathrm{X}_{3}-0.36 \mathrm{X}_{4}-0.00 \mathrm{X}_{5} \leq-204,058,195.92
$$

- Imports:

$$
0.03 \mathrm{X}_{1}+0.05 \mathrm{X}_{2}+0.00 \mathrm{X}_{3}+0.32 \mathrm{X}_{4}+0.10 \mathrm{X}_{5} \leq 1,974,857,337.18
$$

The optimization results in Table 8 shows that the impact of CSO sector to the national economy in final demand $(Y)$ has smaller value than the actual value. While the total output $(X)$ optimization results indicate that the optimal output has a greater value than the actual value.

\section{Conclusions}

The conclusions that can be drawn from the above analysis are as follows:

1) The economic calculations of CSO plant 
development indicate a profitable investment prospects. The analysis result showed thatin the coal price assumption of US\$60/ton, synthetic coal oil price at US $\$ 111 / \mathrm{bbl}$, and the interest rates $(i) 5 \%$, the investation in CSO plant in greater capacity, for example,12,000 tons of coal/day will give a better Internal Rate of Return (IRR) and Profitability Index (PI).

2) The result of backward linkage $\left(\alpha_{j}\right)$ analysis of CSO sector is known can only give a lower yield $\left(\mathrm{S}_{1}: \alpha_{3}=0.942\right.$ and $\left.\mathrm{S}_{2}: \alpha_{3}=0.958\right)$ than the average of backward linkages sectors of economy, but higher than the petroleum refineries products $\left(\mathrm{S}_{1}: \alpha_{12}=0.679\right.$ and $\left.\mathrm{S}_{2}: \alpha_{12}=0.674\right)$ and others providers energy sectors. One reason isthe authorization of the national coal resources that is a source of raw materials for CSO industry by large mining companies. While the forward linkages $\left(\beta_{i}\right)$ of CSO sectoris lower $\left(\mathrm{S}_{1}: \beta_{3}=0.731\right.$ and $\mathrm{S}_{2}: \beta_{3}=0.734$ ) than others energy provider sectors that indicate the lack ability to encourage the growth of downstream sectors.

3) The multiplier of CSO sector in general shows the average values higher than the petroleumr efineries products sector. These values indicates that the synthetic coal oil sector has the potential to create a new output that capable to drive the national economic sectors equivalent to the petroleum refining sector and other energy providers. However, this sector has a surplus multiplier value is lower than other energy providers sector who indicates that CSO plant investment is less able to provide operating surplus that attractive to investors.

4) Government can provide incentives for investment of low rank CSO plant to make it more attractive to investors. The forms of incentives can be given such as regulation support, investing financial support tax incentives/tax holiday, price subsidies, etc.

5) The low value offinal demand optimization results in 2025 I-O Table when compared tothe actual value due to such:

a The value offinal demand ( $\mathrm{Y}=\mathrm{GDP})$ in 2025 is estimated has reached the optimal value;

b CSO industry more efficiently when compared to petroleum refinery as it uses domestic low rank coaland is located close to themine site;

c CSO has an ability to attract economic growth in the upstream than downstream sectors.

\section{References}

[1] Anonymous (a), Gasification World Data Base. U.S. Department of Energy, Office of Fossil Energy, National Energy Technology Laboratory, 2007.

[2] Anonymous (b), Clean Coal Technology Programs: Program Update. U.S. Department of Energy, Assistance Secretary for Fossil Energy, Washington, 2008.
[3] Anonymous (c), Laporan Gasifikasi Batubara Indonesia Volume I, II, III 1999-2000. Departemen Energi dan Sumber Daya Mineral, 2000.

[4] Anonymous (d), Coal Technology. Proceedings of Seminar on Coal Technology and the Indonesian Needs, Jakarta, October 19-26. Republic of Indonesia-Federal Republic of Germany, 1980.

[5] Anonymous (e), Feasibility Study on Direct Liquefaction of Banko Coal in Indonesia. BPPT and NEDO, Kobe Steel Ltd, 2002.

[6] Anonymous (f), Coastal Case-Coal Liquefaction. BPPT, NEDO, Kobelco, 2003.

[7] Anonymous (g), Bahan Menteri ESDM Pada Rapat Kerja Pemerintah dan Peran BUMN Dalam Percepatan dan Perluasan Pembangunan Nasional. Istana Bogor, 21 Februari, 2011.

[8] Anonymous (h), 2011. Low-rank Coal Upgrading Technology Development, Final Report. Research and Development Center for Mineral and Coal Technology (tekMIRA) and Japan Coal Energy Center (JCOAL)/Kobe Steel, Ltd, 2011.

[9] BadanPusatStatistik, Tabel Input-Output Indonesia, Jakarta, Indonesia, 2005.

[10] BP-PEN, Blueprint Pengelolaan Energi Nasional 2006-2025, (BPEN), Jakarta, 2010.

[11] V. Bulmer, and Thomas, I-O Analysis in Developing Countries, John Wiley \& Sons Ltd, London, 1982.

[12] B. Daulay, Techno-Economic Low Rank Coal Projects in Indonesia, PuslitbangTekmira,2008.

[13] Direktorat Jenderal Mineral and Batubara, Statistik Batubara, Jakarta, 2012.

[14] Direktorat Jenderal Minyak dan Gas, Statistik Minyak Bumi, Jakarta, 2012.

[15] M. Huda, and S. Munir, Persiapan Semikomersial Pencairan Batubara, Puslitbang Tekmira, Bandung, 2008.

[16] Menko Perekonomian, Masterplan Percepatan dan Perluasan Pembangunan Ekonomi Indonesia (MP3EI), Tahun2011-2025, 2011.

[17] W.H. Miernyk, The Elements of Input-Output Analysis, Random House, New York, 1965.

[18] W.H. Miernyk, Regional Analysis and Regional Policy, Oelgeschlager, Gunn \&Hain, Publishers, Inc, Cambridge, Massachusetts, 1982.

[19] S. Nazara, Analisis Input-Output, Lembaga Penelitian Fakultas Ekonomi, UI, 2005.

[20] U.W. Soelistijo, "Beberapa Indikator Nilai Tambah Ekonomi Indonesia: Sektor Energi dan Sumber Daya Mineral (Several Indicators of the Indonesia Economy Added Value : Energy and Mineral Resource Sector)," JurnalTeknologi Mineral dan Batubara, vol. 9,No.1, Januari 2013.

[21] U.W. Soelistijo, and R. Damayanti, Waste Gases and Particulates Resulted from Briquette Combustion. Air Quality VIII, An International Conference on Carbon Management, Mercury, Trace Substances, SOx, NOx, and Particulate Matter, Arlington, VA, USA, October 24-27, 2011. 
[22] U.W. Soelistijo, R. Saepudin, T. Suseno, and S.Palamba, Economic evaluation of the NEDO (Japan) - BPPT (Indonesia) feasibility study on the Indonesia Banko coal liquefaction, Proceedings, the Coal Technology Association, "The $28^{\text {th }}$ International Technical Conference on Coal Utilization \& Fuel Systems", Sheraton Sand Key Hotel, Clearwater,Flrorida, USA, March 10-13,2003.
[23] S.Wasaka, Coal Liquefaction Development in NEDO, IEA Coal Industry Advisory Board workshop, 2 November 2006, IEA Headquarters, Paris, 2006. 